REVIEW ARTICLE

\title{
Skeletal Dysplasia: an Analysis of Dwarfism in Ancient Egyptian Culture
}

\author{
Kody Engele* \\ Department of Kinesiology, College of Kinesiology, University of Saskatchewan
}

\begin{abstract}
The purpose of this paper is to analyze dwarfism and its standing in ancient Egyptian society and culture. Dwarfism existed in ancient Egyptian society, but unlike other ancient societies, those with dwarfism were not blatantly discriminated against (Sullivan 2001). Individuals with dwarfism could hold many positions within society ranging from herdsmen and fishermen, to personal attendants in royal court (Kozma 2008). There is evidence of individuals with dwarfism dating back to the Badarian Period, with statues, sarcophagi, skeletons, and paintings all having been discovered (Kozma 2008). There are several prominent figures who have been studied in detail; Per-ni-ankh-w was an individual with high status in Egyptian society, and there is ample documentation of him in texts, visual imagery, and skeletal evidence (Kozma 2008). Djeho was another individual who has been well documented and aided with burials (Kozma 2008). Individuals with dwarfism also had religious importance, including the gods Bes and Ptah (Kozma 2008). Individuals with dwarfism were also considered to hold magical significance, and this was seen in spells and religious texts (Kozma 2008). Additionally, there is an abundance of artistic representation of individuals with dwarfism, in the form of statues, sarcophagi, and visual images (Kozma 2008). The Walters Art Museum is also a significant holder of Egyptian art, with many depictions of dwarfism (Kozma 2010). These individuals were significant in ancient Egyptian society and were well documented in several forms.
\end{abstract}

Keywords: skeletal dysplasia, dwarfism, achondroplasia, hypochondroplasia, osteology, iconography, Walters Art Museum

\section{INTRODUCTION}

Skeletal Dysplasia in modern society is often considered taboo, or enigmatic, and individuals afflicted with the condition are regularly subjected to scrutiny and objectification; however, in ancient Egyptian society, individuals with skeletal dysplasia existed harmoniously with the rest of the population. In this region those affected with skeletal dysplasia, more commonly known as dwarfism, were not regarded with disdain or distaste, which was common in other ancient societies such as Greece or Rome (Sullivan 2001, 262-6). Instead, individuals with dwarfism were viewed positively in ancient Egyptian culture and were often depicted with youthful qualities and frequently associated with certain deities such as Bes, Ptah, and Horus (Sullivan 2001, 262). This paper will begin with medical terminology and an overview of skeletal

\footnotetext{
* Corresponding author (kle906@usask.ca)
} 
dysplasia, followed by a brief history of study, and osteological explanation of skeletal dysplasia. Next, the depiction of individuals with dwarfism will be explored, followed by a discussion of collections of ancient Egyptian art, and examinations of where the art was first uncovered. The social status of known individuals with skeletal dysplasia such as Per-niankh-w and Djeho will then be examined. Buried with these individuals was an abundance of evidence in the forms of statues, tomb paintings, and coffin texts that attest to their social status and duties. Following this, the religious and magical importance of people with dwarfism will be discussed. Figures, amulets, and papyri of magical significance have been found, and several gods are depicted with dwarfism (Kozma 2008, 3104-3112). Artistic evidence of people with dwarfism will then be examined. There is an abundance of artistic representations from many different sites showcasing the different types of skeletal dysplasia, which give insight into the life and position of the individual depicted. This paper will discuss how persons with skeletal dysplasia in ancient Egypt could gain considerable status within society and were positively represented in artistic, religious, and magical contexts.

\section{MEDICAL TERMINOLOGY}

Skeletal dysplasia is an all-encompassing term for those affected by dwarfism, and it includes conditions such as achondroplasia, hypochondroplasia, and osteogenesis imperfecta, (Dasen 1988, 255). There are over four hundred different types of skeletal dysplasia, but the condition itself is quite rare (Calder and Foley 2018, 84-92). Most disorders are inherited genetically. The genetic mutation causing skeletal dysplasia alters genes involved in the development process of the entire skeleton, and there are 364 known genes involved (Calder and Foley 2018, 84). The most common type of dwarfism is achondroplasia, which can sometimes be referred to as short- limbed dwarfism (Calder and Foley 2018, 84). The disorder results from a gene mutation and is an autosomal dominant trait, meaning it can be passed on to offspring; however, most cases are the result of a new mutation (Calder and Foley 2018, 88). The disorder causes slowed longitudinal growth of the long bones, and early closure of the joints of the axial skeleton (Calder and Foley 2018, 88). This results in individuals having short limbs, a large cranial vault, small facial bones, and a normal trunk (Dasen 1988, 255). Hypochondroplasia is just as common as achondroplasia but is a milder form of dwarfism (Dasen 1988, 255). Like achondroplasia, hypochondroplasia is usually caused by new gene mutations but can also be passed on genetically (Glasgow, Nevin, and Thomas 1978, 871). Individuals affected by hypochondroplasia have short limbs and lumbar lordosis, an inward curve of the lower spine; however, the extreme short stature and the small facial bones that are seen in achondroplasia are not present in those with hypochondroplasia (Glasgow, Nevin, and Thomas 1978, 871). Osteogenesis imperfecta also has an autosomal dominant inheritance pattern, but like achondroplasia and hypochondroplasia, most new cases are caused by mutation, specifically in the genes that code for collagen (Calder and Foley 2018, 87). The distinct characteristics of this conditions are a blue sclera of the eye, discoloured teeth, hypermobility of the skin and joints, hearing impairments, and brittle bones (Rauch and Glorieux 2004, 1377). Additionally, there are at least 19 different types of the condition which range in severity (Rauch and Glorieux 2004, 1377). Most skeletal evidence of dwarfism consists of individuals with achondroplasia, and the condition is most easily identified by examining the spine, long bones, and skull (Dasen 1993, 14).

\section{HISTORY OF STUDY}

In ancient Egypt there is a long history of individuals afflicted with skeletal dysplasia, with skeletons dating back as early as the 
Badarian Period, 4400-4000 BCE (Kozma 2008, 3105). Individuals with dwarfism in ancient Egypt have been studied by many wellknown archaeologists. For example, John Garstang excavated at Beni Hasan, and Auguste Mariette found the tomb of Khnumhotep at Saqqara (Dawson 1938, 186). James Quibell also uncovered the tomb of Djeho, which contained his unique sarcophagus (Dawson 1938, 186). These excavations brought to light several examples of notable individuals of dwarfism. Since archaeologists began examining people with dwarfism, the field has advanced alongside regular archaeological excavation. Techniques now include advanced medical analyses that help archaeologists examine the bones and diagnose rarer, more specific forms of skeletal dysplasia (Kozma 2008, 3106).

\section{OSTEOLOGY}

Osteology is the scientific study of bones, which is critical for discovering skeletal dysplasia in any individual. There is skeletal evidence of dwarfism from as early as the Badarian Period (Kozma 2008, 3105-106). The Badarian Period lasted from approximately 4400-4000 BCE, and during this time the first early farming culture with standardized organization was developed (Shaw and Ian 2003, 39). The Badarian Culture resided in Upper Egypt, and had a well-established practice of fishing, agriculture, and animal husbandry (Shaw, and Ian 2003, 39). In addition to this, hundreds of graves with thousands of remains have been discovered from this period, including skeletons with skeletal dysplasia (Dawson 1938; Kozma 2008; Shaw, and Ian 2003). Analysis of the Badarian skeleton in Figure 1 shows that the individual had skeletal dysplasia. While their skull was of a normal size, their humerii, radii, and ulnae were all smaller than normal (Kozma 2008, 3105-106). These characteristics are suggestive of short-limbed dwarfism, but the exact

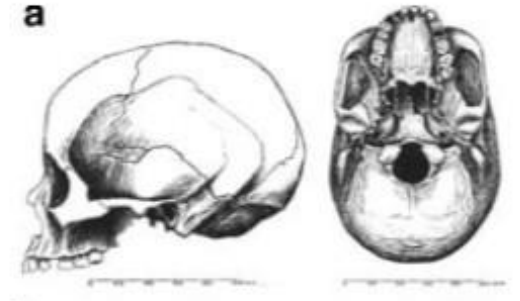

b

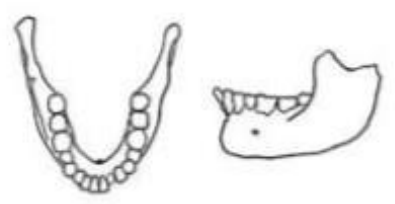

C

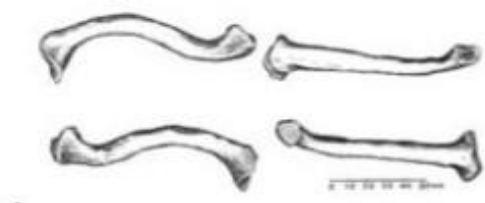

d
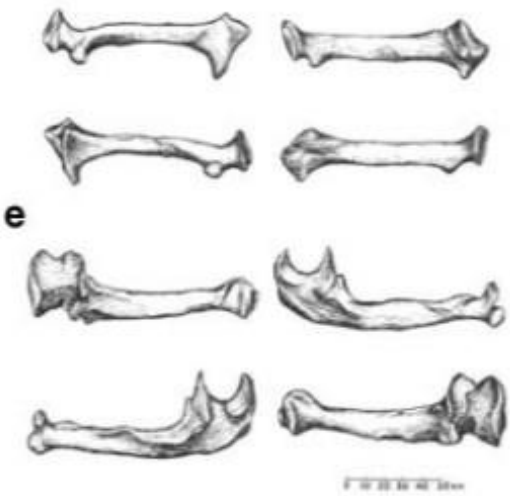

f

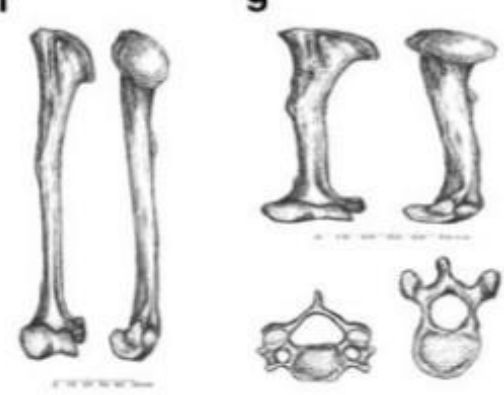

FIGURE 1-A drawing of a skeleton from the Badarian Period, illustrating the skeletal markers of dwarfism. (a) Skull, (b ) mandibles, (c) clavicles, (d) radii, (e) ulnae, $(\boldsymbol{f})$ humeri, (g) vertebrae (Kozma 2008). Reproduced with permission from the American Journal of Medical Genetics Part A, John Wiley \& Sons. 
condition has been disputed (Kozma 2008, 3105-106).

Other skeletons dating to predynastic times, approximately 4000-3000 BCE, were found at Hierakonpolis, and Beni Hasan (Dawson 1938, 186). Both Hierakonpolis and Beni Hasan were located in Upper Egypt, what is now the southern part of modern Egypt. The tomb complex of King Wadj contained a skeleton dating to between 3100-2800 BCE. This skeleton was found to have had extremely short limbs, which is suggestive of achondroplasia (Kozma 2008, 3106). At the site of Abydos, in Upper Egypt, the skeletons of three individuals with dwarfism, as well as the humerus of another, have all been found, and all appear to have signs of achondroplasia (Dawson 1938, 186). The tombs of Khnumhotep and Djeho were uncovered at Saqqara, and the tomb of Seneb was located at Giza (Dawson 1938, 187). The sites of both Saqqara and Giza were located in Lower Egypt, currently the northern part of modern Egypt. Both Khnumhotep and Seneb were high officials in court, and each tomb contained statues, sculptures, sarcophagi, or skeletal evidence indicating the presence of dwarfism (Dawson 1938, 186-87). Per-ni-ankh-w, an elite member of society, was very well documented through artistic renditions and had an intact tomb complete with his skeleton, which allowed for the study of his bones. The skeleton showed the trademark signs of achondroplasia (Kozma 2008, 3106). These individuals, along with the nameless skeletons, are just a few of the many examples of dwarfism in ancient Egypt, showcasing when and where these people existed.

\section{ARTISTIC REPRESENTATION}

\section{Sites}

There are countless artistic representations of individuals with dwarfism from ancient Egypt, ranging from regular people to gods. There is artistic evidence from as early as predynastic Egypt (prior to $3100 \mathrm{BCE}$ ), up until the Greco-Roman Period (332 BCE-395 AD; Kozma 2010, 2556). The sites of Naqada and Ballas, both in Upper Egypt, contained small ivory figurines of individuals with dwarfism, showing that people with dwarfism were being commemorated as early as predynastic times (Dasen 1988, 260). At Abydos, nine stelae were found dedicated to individuals of the court who suffered from dwarfism (Dasen 1988, 260). This is noteworthy as it shows that those with dwarfism could achieve status in the royal court and even receive commemoration. In the tomb of Mereruka, there is a depiction of four bald people with dwarfism making necklaces (Dasen 1988, 260). The baldness is of note because it was a typical characteristic of herdsmen or fishermen, which indicates that dwarfs could be both ordinary and elite members of society (Dasen 1988, 260). However, the fact that they were depicted in a tomb is of significance, as they would have been of some importance within society. In addition to statues of gods, renditions of ordinary people with dwarfism were often found in tombs at Saqqara and Giza, usually performing ordinary tasks such as herding and fishing (Kozma 2008, 3110). The Walters Art Museum has a collection of such statues; these statues depict the individuals participating in a range of activities, such as dancing, working (Figure 2), or entertaining. Many are shown with harmful animals, such as crocodiles, which highlights their protective role, similar to Figure 6 of the god Ptah (Kozma 2010, 2560). The act of placing statues of common people with dwarfism in tombs is a testament to the ritualistic importance of individuals with dwarfism as they were deemed necessary to accompany the deceased to the afterlife. Sarcophagi inscriptions, such as on Djeho's sarcophagus, detail the lives of the individual and their place in society. Figures and amulets are also prevalent, especially regarding religious or magical importance. 


\section{Artistic Depiction}

The physical representation of dwarfism is mostly standard throughout ancient Egypt. The overall features of dwarfism are well displayed - large head, long trunk, and short, often bowed limbs (Dasen 1988, 267). Finer details are also occasionally added, including a rounded forehead, large thighs, and tilted (Dasen 1988, 267). However, the three features that are standard to artistic representations in ancient Egypt are not always accurate

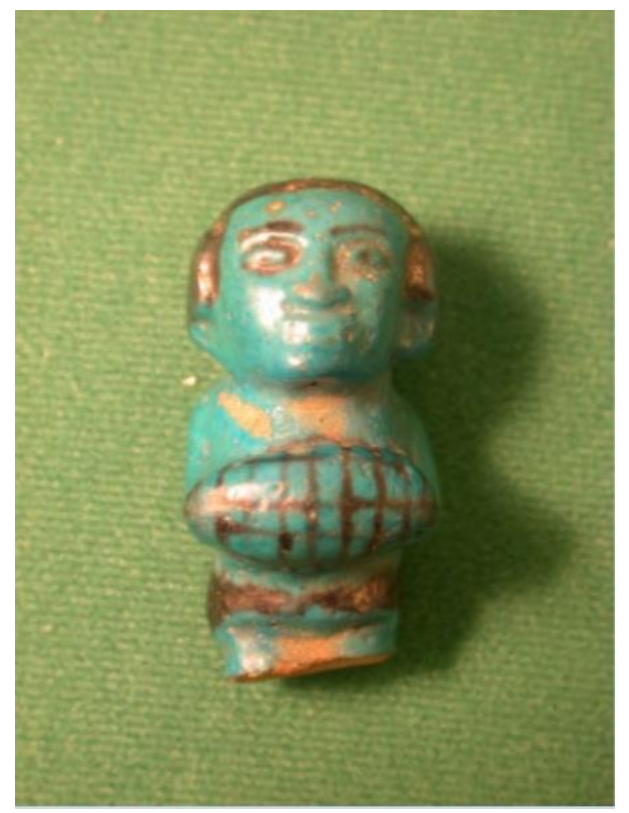

FIGURE 2-An image of a statue of an ordinary dwarf, found at the Walters Art Museum (Kozma 2010). Reproduced with permission from the American Journal of Medical Genetics Part A, John Wiley \& Sons.

pelvis but have an important meaning. First, in nearly all depictions, people with dwarfism are displayed with normal faces which suggests a respect for the individual's legacy (Dasen 1988, 267). Secondly, short stature is also exaggerated, suggesting that their height was of importance to the elite who employed them. Lastly, a flat skull was used to stress the religious importance of dwarfs, which which symbolized the reverence for Ptah, who was often depicted with a flat skull (Dasen 1988, 268).

\section{KNOWN INDIVIDUALS}

\section{Per-Ni-Ankh-W}

In ancient Egypt, people with dwarfism fulfilled many different roles and duties, often consisting of important positions within the court. These roles included taking care of jewellery and pets, or acting as personal attendants (Dawson 1938, 187). There are

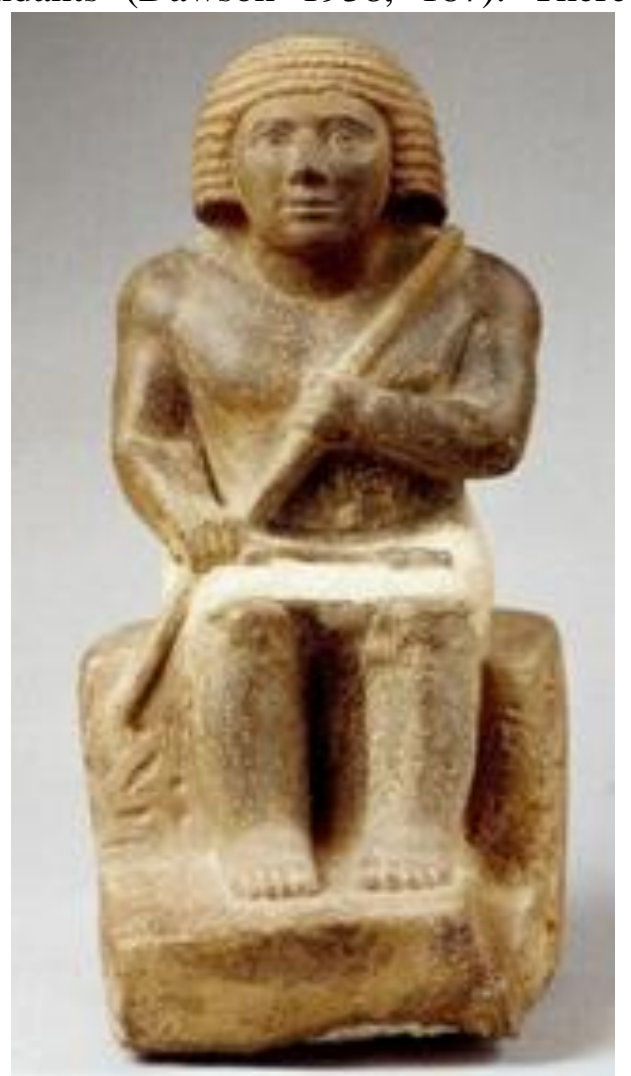

FIGURE 3 - An image of the statue of Per-niankh-w, which was discovered in his tomb (Kozma 2008). Reproduced with permission from the American Journal of Medical Genetics Part A, John Wiley \& Sons.

textual, and osteological evidenceseveral wellknown individuals who achieved higher status and are well represented in iconographic.

The Old Kingdom, lasting from 27002190 BCE, was home to Per-ni-ankh-w. The Old Kingdom was a peaceful and prosperous time, marked by the building of the pyramids, 
including the Great Pyramid of Giza. Per-niankh-w was court official in the fifth or sixth Dynasty, the later part of the Old Kingdom (Kozma et al. 2011, 1817-1824). This man was a well-documented individual, allowing for archaeologists to uncover several details regarding his life. Both sides of his chair, shown in Figure 3, bear the inscription "the dancing dwarf in the Great Palace, the one who pleased his majesty everyday, Per-ni-ankh-w," indicating he was close to the king (Kozma 2005, 307). This is noteworthy as it shows that someone affected by dwarfism could ascend to a place in society where their relationship with the king was of enough consequence to be inscribed on their statue. Per-ni-ankh-w is important for aiding in the understanding of skeletal dysplasia in ancient Egypt because he has biological, artistic, and textual evidence detailing his life. The fact that he was important enough to receive a tomb rather than a common grave is also a distinct indicator of status. In Figure 3, Per-ni-ankh-w's dwarfism is apparent in the short upper and lower limbs, as well as the short neck (Kozma 2008, 3107).

\section{Djeho}

Another well-known individual with dwarfism is Djeho, who was buried at Saqqara around the year $345 \mathrm{BCE}$ with his patron Tjaiharpta (Baines 1992, 241-257). Tjaiharpta was the highest ranking financial official in the country, holding the title of sntj; in contrast, Djeho held no high title but was associated with the Cult of the Bulls (Baines 1992, 250). According to Baines (1992), "Djeho was specially qualified by his physical abnormality to perform the cult dances, and so had a privileged role in the burials of the sacred bull" (255). The relationship between Djeho and Tjaiharpta is quite interesting. They were buried together and had inscriptions on their respective sarcophagi that referred to each other. In addition to this, on Djeho's sarcophagus, there is a full-length profile portrait of himself, seen in Figure 4.

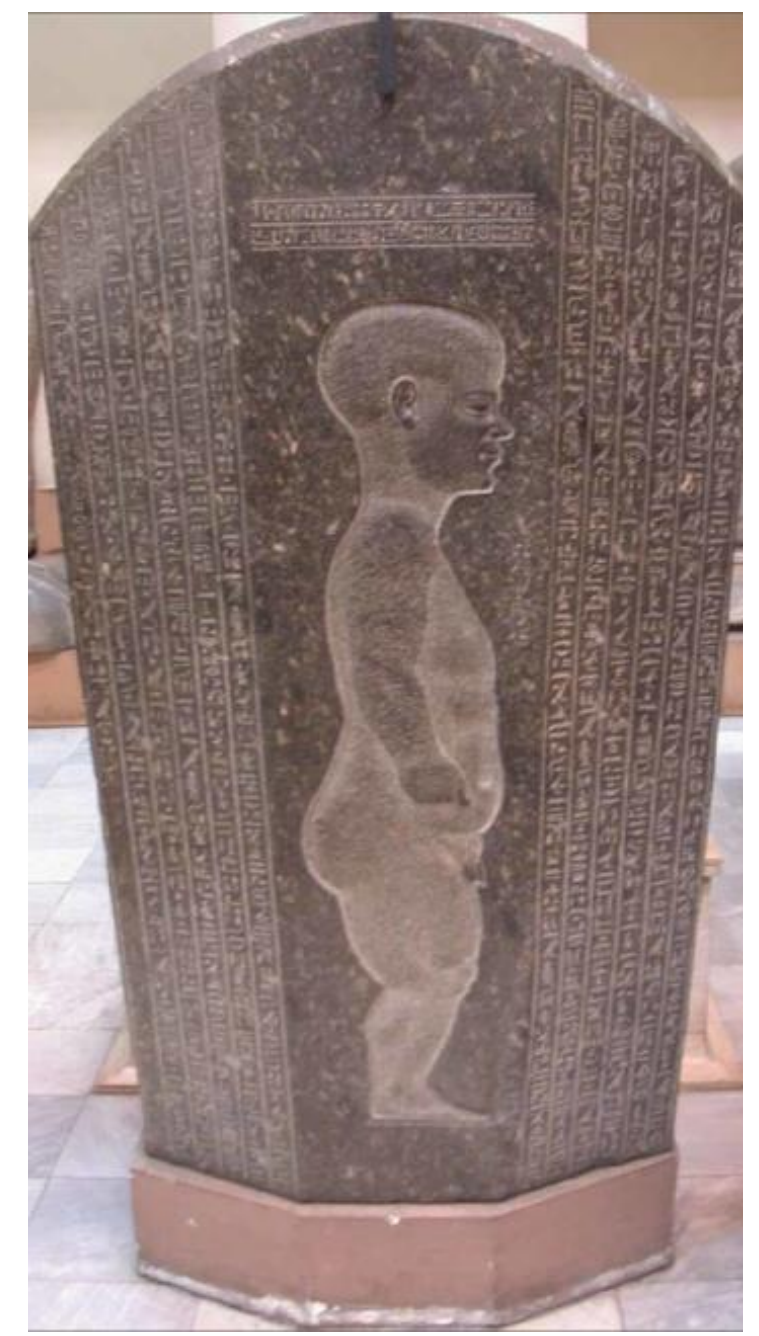

FIGURE 4-An image of Djeho's sarcophagus (Kozma 2005). Reproduced with permission from the American Journal of Medical Genetics Part A, John Wiley \& Sons.

His dwarfism is clearly pronounced in this depiction, highlighted by the short limbs, tilted pelvis, and squat stature. Djeho's sarcophagus also has messages asking for Tjaiharpta to have a good life and easy passage to the afterlife (Baines 1992, 250). Normally in ancient Egypt, a sarcophagus would contain purely religious texts, and in this case, it appears as if the figure was added after the original inscription (Baines 1992, 249). These unique sarcophagi inscriptions are interesting because they defy the normal ancient Egyptian funerary traditions and indicate that both individuals had a high enough status within society to have 
these sarcophagi made. Their burial place of Saqqara is also notable because the necropolis was used extensively by pharaohs in the Old Kingdom (Shaw and Ian 2003, 70). To be buried here, the deceased must have been of high status or importance within ancient Egyptian society.

\section{RELIGIOUS AND MAGICAL IMPORTANCE}

\section{Bes}

Bes and Ptah, two Gods with dwarfism, played important roles in the protection of both the living and the dead (Kozma 2008, 3109). Bes, god of music and warfare, is a protector of the household and is depicted with dwarfism (Kozma 2008, 3109). His most important role was the protection of women during childbirth. So important was this role that there is a specific papyrus and spell associated with him. The magical papyrus at Leiden contains a "Spell of the Dwarf," which helps facilitate childbirth (Kozma 2008, 3109). The directions of the spell say to recite the following words: "O good dwarf, come, because of the one who sent you . . come down placenta, come down placenta, come down," four times over a statue of Bes (Figure 5) that has been placed on the woman, which will ensure safe delivery of the child (Kozma 2008, 3109; Dawson 1938, 188).

\section{Ptah}

Ptah, another god with dwarfism, is the creator of the universe, god of craftsmen, and patron god of Memphis (Kozma 2008, 3110). The god Ptah is only sometimes depicted with dwarfism and is often seen with a scarab beetle on top of his flattened skull (Dasen 1988, 268). Ptah played an important protective role, frequently being shown holding snakes or standing on crocodiles, such as in Figure 6, to represent his defensive role towards harmful creatures (Kozma 2008 3109-10). When depicted as a dwarf, Ptah is very distinct from

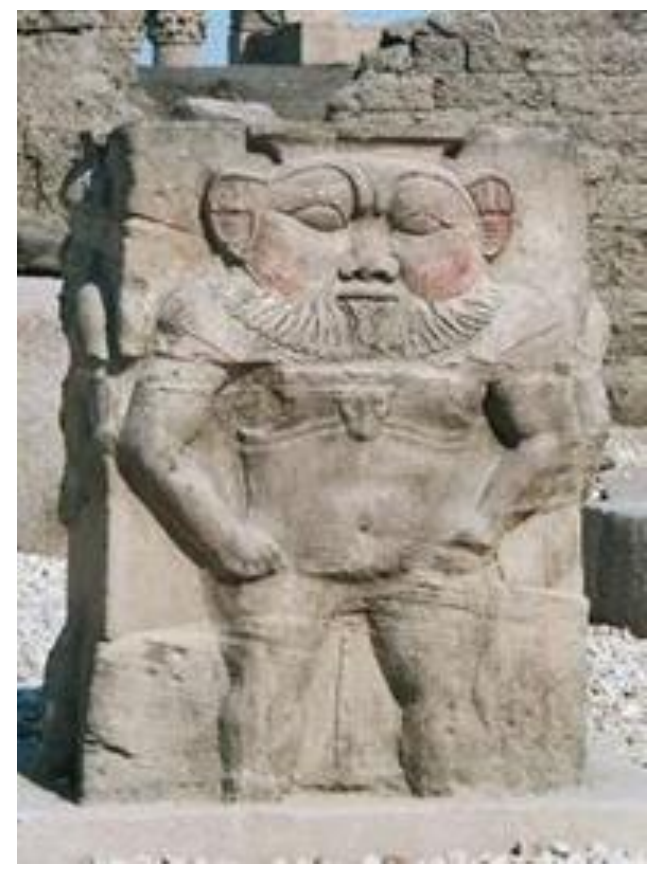

FIGURE 5-An image of the statue of the god Bes (Kozma, 2008). Reproduced with permission from the American Journal of Medical Genetics Part A, John Wiley \& Sons.

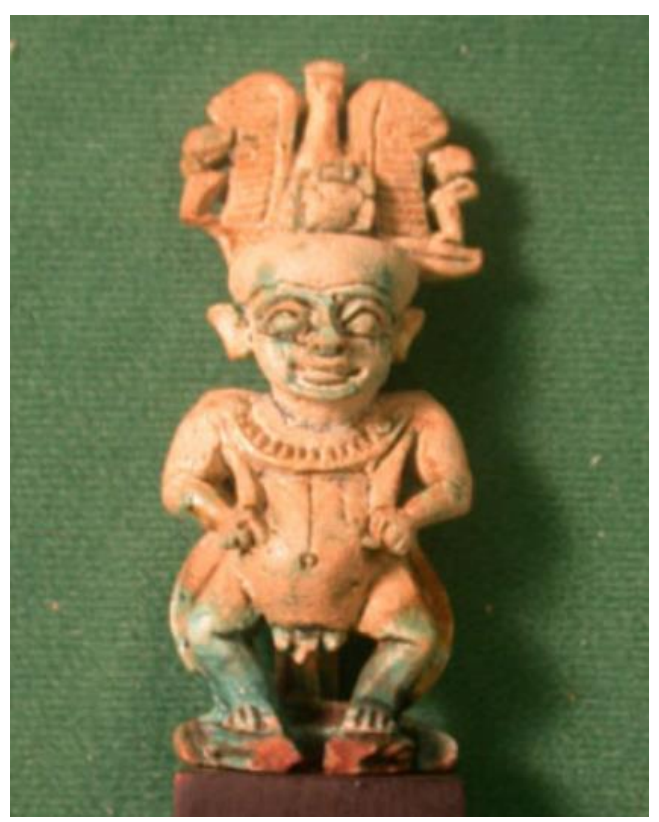

FIGURE 6-An image of the statue of the god Ptah standing on crocodiles and holding a knife in each hand (Kozma 2010). Reproduced with permission from the American Journal of Medical Genetics Part A, John Wiley \& Sons. 
Bes; in comparing Figure 6 to Figure 5, the difference in stature is very apparent. Bes is depicted in a squatting posture, whereas Ptah has a longer trunk. They both have short limbs, but Ptah is also depicted naked. The apparent dwarfism of these two gods shows that the ancient Egyptian people held those with skeletal dysplasia in high regard within their society. Additionally, it also demonstrates that individuals with dwarfism are viewed as important members of ancient Egyptian culture.

\section{Magical Significance}

People with dwarfism also had religious and magical significance outside the form of gods. Besides the magical papyrus at Leiden, another magical papyrus also has an individual with dwarfism mentioned in the spell: "O thou dwarf of heaven! O Thou dwarf of heaven! Thou dwarf whose face is big, whose back is long and whose legs are short" (Dawson 1938, 188). The mention of a dwarf of heaven is important as it illustrates the magical meaning of people with dwarfism, and further highlights that they could achieve high status within society and religion. In the 147th and 164th spell in the Book of the Dead, pictures of individuals with achondroplasia are shown, which demonstrates their magical importance in ensuring safe passage to the afterlife (Dawson 1938, 188). There are also very early depictions of people with dwarfism in the form of figurines and amulets, and they are seen in funerary papyri much later (Dawson 1938, 188). The abundant representation of individuals with dwarfism in religious texts and spells, as well as two gods with dwarfism, showcases the religious and magical importance that dwarfs held within Egyptian society.

\section{CONCLUSION}

In ancient Egypt, skeletal dysplasia is abundantly represented. Examination of the artifacts and skeletal remains that display evidence of dwarfism is important because it allows for the intricacies of social acceptance in ancient Egyptian culture to be more thoroughly understsood. There are many examples of individuals who gained rank within the court, such as Per-ni-ankh-w and Djeho, and their role within society and importance to the King is well documented. The gods Bes and Ptah are very well known, and both play important roles in the protection and creation of the ancient Egyptian people. Various spells, papyri, amulets, and sarcophagi inscriptions also demonstrate the magical importance of people with dwarfism and their role in the afterlife. The abundance of iconographic representations of individuals with dwarfism ranging from the Predynastic Period to the Greco-Roman Period helps document these indvidiuals throughout the history of ancient Egypt and shows their changing roles in society. These representations also showcase that individuals with dwarfism were permitted to lead normal lives, free from discrimination that was abundant in other ancient societies, and could rise above their station to lead important roles within the court. Based on these observations, it is clear that people with dwarfism were important and respected members of ancient Egyptian civilisation, with roles in every aspect of society from herdsmen, to officials in the royal court, to gods.

\section{REFERENCES}

Baines, John. 1992. "Merit by Proxy: The Bibliographies of the Dwarf Djeho and His Patron Tjaiharpta." The Journal of Egyptian Archaeology 78, no. 1 (October): 241-257. https://doi.org/10.1177/0307513 39207800114

Calder, Alistair D. and Patricia Foley. 2018. "Skeletal Dysplasias: An Overview." Paediatrics and Child Health 28, no. 2 (February): 84-92. https://doi.org/10.10 16/j.paed.2017.10.001

Dasen, Véronique. 1988. "Dwarfism in Egypt and Classical Antiquity: Iconography and 
Medical History." Medical History 32, no. 3 (July): 253-276. https://doi.org/10.1017/ S0025727300048237

Dasen, Véronique. 1993. Dwarfs in Ancient Egypt and Greece. Oxford: Oxford University Press.

Dawson, Warren R. 1938. "Pygmies and Dwarfs in Ancient Egypt." The Journal of Egyptian Archaeology 24, no. 2 (December): 185-189. https://doi.org/10.2307/38 54789

Glasgow, John F. T., Norman C. Nevin, and Patricia S. Thomas. 1978. "Hypochondroplasia." Archives of Disease in Childhood 53, no. 11 (November): 868-872. http://dx.doi.org/10.1136/adc.53.11.868

Kozma, Chahira. 2005. "Dwarfs in Ancient Egypt." American Journal of Medical Genetics Part A 140A, no. 4 (December): 303-311. https://doi.org/10.1002/ajmg.a.3 1068

Kozma, Chahira. 2008. "Historical Review II: Skeletal Dysplasia in Ancient Egypt." American Journal of Medical Genetics Part A 146, no. 23 (November): 31043112. https://doi.org/10.1002/ajmg.a.325

01

Kozma, Chahira. 2010. "The Ancient Egyptian Dwarfs of the Walters Art Museum." American Journal of Medical Genetics Part A 152, no. 10 (May): 2556-2562. https://doi.org/10.1002/ajmg.a.33616

Kozma, Chaira, Azza M. Sarry El Din, Rokia A. El Shafy El Banna,Wafaa A. El Samie Kandeel, and Ralph Lachman. 2011. "The Ancient Egyptian Dwarfs of the Pyramids: The High Official and the Female Worker." American Journal of Medial Genetics Part
A 155 , no. 8 (June): 1817-1824. https://doi.org/10.1002/ajmg.a.34038

Rauch, Frank and Francis H. Glorieux. 2004. "Osteogenesis imperfecta." The Lancet 363, no. 9418 (April): 1377-1385. https://doi. org/10.1016/S0140-6736(04)16051-0

Shaw, Ian, ed. 2003. The Oxford History of Ancient Egypt. Oxford University Press.

Sullivan, Richard. 2001. "Deformity: A Modern Western Prejudice with Ancient Origins." Royal College of Physicians of Edinburgh 31, no. 3 (February): 262-266. 